\title{
Estimation of Serum Osteocalcin Levels in Osteoporotic Postmenopausal Iraqi Women with Type 2 Diabetes Mellitus
}

\author{
Kadhim K. Ghudhaib* \\ Kismat M.Turaki** \\ Sabreen A. Muzal*
}

Received 30, September, 2013

Accepted 9, December, 2013

\begin{abstract}
:
Background: Osteoporosis (OP) is a systemic disease characterized by low bone mass and micro architectural deterioration of bone tissue, resulting in an increased risk of fractures and has touched rampant proportions. Osteocalcin, one of the osteoblast-specific proteins, showed that its functions as a hormone improves glucose metabolism and reduces fat mass ratio. This study is aimed to estimate the osteocalcin and glucose level in blood serum of osteoporotic postmenopausal Women with and without Type 2 Diabetes.

Materials and methods: 60 postmenopausal women with osteoporosis divided into two groups depending on with or without T2DM, 30 patients for each. Serum samples of 30 healthy postmenopausal women were collected as control group. Osteocalcin was measured by ELISA method using a kit of (CUSABIO. China). Glucose was determined by spectrophotometric method.

Results: Mean serum osteocalcin in postmenopausal osteoporotic women without Type II Diabetes is higher than control group and the group with T2DM $(\mathrm{p} \leq 0.001)$.

Conclusion: Bone formation marker increases at postmenopausal osteoporosis women; Hyperglycemia also induces osteoblast function and reduces of production osteocalcin at T2DM.
\end{abstract}

Key words: Osteocalcin, Glucose, Osteoporosis, T2DM.

\section{Introduction:}

Osteoporosis is a systemic disease characterized by low bone mass and micro architectural deterioration of bone tissue, resulting in an increased risk of fracture and has touch rampant proportions [1]. According to WHO, $30 \%$ of postmenopausal women and $70 \%$ of women aged above 80 are affect by osteoporosis [2].

Osteoporosis is one of the health problems arising in women entering menopausal age, and will presumably seriously affect the lives of postmenopausal women. Osteoporosis and the potentially serious consequences of osteoporotic fracture increase with advancing age of the population, making skeletal health assessment an important component of routine care in postmenopausal women [3].

Diabetes mellitus is a common disease in most parts of the world [4]. It affects skeletal system and bone metabolism through multiple pathways and it has been recognized as a major risk factor for osteoporosis [5].

Several mechanisms have been proposed for diabetes-related osteoporosis. Poor glycemic control can induce hypercalciuria which has been considered a potential risk factor for osteoporosis in patients with type 2 diabetes [6].

Osteocalcin (OC), Osteocalcin, also known as "bone gamma-

*Department of Chemistry, College of Science for women, Baghdad University, Baghdad, Iraq.

**Branch of Clinical Biochemistry, College of Medicine, Baghdad University, Baghdad, Iraq. 
carboxyglutamic acid (Gla) protein (BGP)," is the most abundant no collagenous protein of bone matrix [7]. In almost all cases of osteoporosis the resorption rate can far exceed the formation. Osteocalcin is synthesized during the bone formation [8] .Lee et al. showed that $O C$ functions as a hormone that improves glucose metabolism and reduces fat mass, [9].

Clinically, serum OC level is utilized as a bone formation marker, because OC is synthesized by osteoblast Therefore, vitamin-K dependent gamma-carboxylate OC, which binds to hydroxyapatite in bone [10].

The aims of this work is to estimate the osteocalcin and glucose levels in blood serum of postmenopausal osteoporosis women with T2DM, and test the effect of diabetes on osteocalcin level in postmenopausal osteoporosis women with diabetes group in comparison of postmenopausal osteoporosis women without diabetes.

\section{Materials and Method:}

This study was conducted from December 2012 to June 2013. Samples were collected from 90 postmenopausal women, which were selected from patients who visited Rheumatology and Rehabilitation Outpatient Clinic in Baghdad Teaching Hospital. Postmenopausal status was defined by the absence menses for more than one year in a woman 50 years of age and over. Patients were divided into two groups. Group A, includes a total of 30 patients (postmenopausal women) complaining from osteoporosis and diabetes with a mean age (61.27 \pm 5.67 years). Group B includes a total of 30 patients (postmenopausal women) complaining from osteoporosis without diabetes, with a mean age $(62.33 \pm 8.41)$ and Control, this group including 30 apparently healthy controls (postmenopausal women) mean age
(60.18 \pm 6.47). The phlebotomy protocol specified a blood draw after a 12-h fast for all study participants.

The blood samples were allowed to clot and then sera were separated by centrifugation at $3000 \mathrm{rpm}$ for $10 \mathrm{~min}$ at room temperature. Serum was aliquot into storage vials, labeled, and frozen at $-20^{\circ} \mathrm{C}$, until used for the hormones analyses. Patients were diagnosed as osteoporosis and controls as normal by measuring bone mineral density (BMD), using dual energy $\mathrm{x}$ ray absorptiometry (DXA) according to World Health Organization (WHO) diagnostic.

T-score -1.0 or greater is "normal".

T-score between -1.0 and -2.5 is "osteopenia".

T-score -2.5 or below is "osteoporosis".

Serum investigations were included Glucose measuring by spectrophotometer and serum osteocalcin measuring by enzyme linked immunosorbent assay (ELISA) using kit manufactured by (CUSABIO. China)[11].

Anthropometrics measurement: weight in kilogram and height in meter were measured for each women and body mass index (BMI) was calculated using the following equation: BMI = weight in kilogram / height in meter $^{2}$ [12]. Fat $\%$ was calculated using the following equation: Fat $\%=(1.20$ $\mathrm{x}$ BMI $)+(0.23 \mathrm{x}$ Age $)-(10.8 \mathrm{x}$ gender) - 5.4 [13], where male gender $=1$ and female $=0$.

\section{Statistical analysis}

Statistical analyses were performed using SPSS for Windows (version 17). The results were expressed as the mean \pm S.D. Student ANOVA was used for statistical analysis, $\mathrm{P} \leq 0.05$ were considered statistically.

\section{Results:}

[Mean \pm SD] of body mass index $[\mathrm{BMI}]$, waist circumference $[\mathrm{WC}]$ and 
fat $\%$ for the studied groups are shown in Table (1). The results showed that WC of A group is significantly higher than $\mathrm{B}$ and control groups, $[\mathrm{P}<0.001]$, Also WC of B group is significantly higher than control groups, $[\mathrm{P}<0.01]$. The results were not recorded any significant differences of BMI and Fat $\%$ in both patient groups in comparison with control.

Table 1: shows Anthropometrics parameters of the patient and healthy groups.

\begin{tabular}{|c|c|c|c|}
\hline \multirow{2}{*}{ Characteristic } & \multicolumn{2}{|c|}{ Patient groups } & Control group \\
\cline { 2 - 4 } & $\begin{array}{c}\text { Group A } \\
\text { Osteoporosis patients } \\
\text { with diabetes } \\
{[\mathrm{n}=30]}\end{array}$ & $\begin{array}{c}\text { Group B } \\
\text { Osteoporosis patients } \\
\text { without diabetes } \\
{[\mathrm{n}=30]}\end{array}$ & $\begin{array}{c}\text { Group C } \\
{[\mathrm{n}=30]}\end{array}$ \\
\hline BMI $\left[\mathrm{Kg} / \mathrm{m}^{2}\right]$ Mean $\pm \mathrm{SD}$ & $27.83 \pm 4.25$ & $26.45 \pm 3.05$ & $26.87 \pm 1.98$ \\
\hline W. C. $[\mathrm{cm}]$ Mean \pm SD & $93.77 \pm 18.17^{\mathrm{b}, \mathrm{c}}$ & $77.87 \pm 7.47^{\mathrm{a}}$ & $83.87 \pm 3.91$ \\
\hline Age $(\mathrm{y})$ Mean $\pm \mathrm{SD}$ & $61.27 \pm 5.67$ & $62.33 \pm 8.41$ & $60.18 \pm 6.47$ \\
\hline Fat\% Mean \pm SD & $13.90 \pm 4.96$ & $12.01 \pm 3.74$ & $12.99 \pm 2.49$ \\
\hline
\end{tabular}

Results were expressed as the mean \pm SD.

a $\mathrm{P}<0.01$ compared with control group.

b $\mathrm{P}<0.001$ compared with control group .

c $\mathrm{P}<0.001$ compared with group $\mathrm{B}$.

Values of osteocalcin and glucose in group A, group B and group $\mathrm{C}$ are shown in Table [2]. The results showed that osteocalcin level in group $\mathrm{A}$ is significantly lower than groups $\mathrm{B}$ and $\mathrm{C}$.

Table 2: Mean \pm SD concentrations of osteocalcin $[\mathrm{ng} / \mathrm{ml}]$, glucose $[\mathrm{mmol} / \mathrm{l}]$ in patient and control groups.

\begin{tabular}{|c|c|c|c|}
\hline \multirow{2}{*}{ Characteristic } & \multicolumn{2}{|c|}{ Patient groups } & Control group \\
\cline { 2 - 4 } & $\begin{array}{c}\text { Group A Osteoporosis } \\
\text { patients with T2DM } \\
{[\mathrm{n}=30]}\end{array}$ & $\begin{array}{c}\text { Group B } \\
\text { Osteoporosis patients } \\
\text { without T2DM } \\
{[\mathrm{n}=30]}\end{array}$ & $\begin{array}{c}\text { Group C } \\
{[\mathrm{n}=30]}\end{array}$ \\
\hline Osteocalcin[ng/ml]Mean \pm SD & $5.706 \pm 1.337^{\mathrm{c}, \mathrm{b}}$ & $12.708 \pm 3.428^{\mathrm{a}}$ & $9.401 \pm 3.038$ \\
\hline F.S.glucose[mmol/l]Mean \pm SD & $9.39 \pm 1.23^{\mathrm{a}, \mathrm{c}}$ & $5.09 \pm 0.66^{\mathrm{a}}$ & $4.70 \pm 0.448$ \\
\hline
\end{tabular}

Results were expressed as the mean \pm SD.

$\mathrm{a}: \mathrm{P}<0.01$ group compared with control group.

b: $\mathrm{P}<0.001$ group compared with group $\mathrm{B}$.

c: $\mathrm{P}<0.001$ group compared with control group.

Table 3: shows the application of simple regression analysis which revealed appositive significant correlation between serum Osteocalsin levels and serum F.S.G for patient groups and control.

\begin{tabular}{|l|c|c|}
\hline Groups & Correlation & P value \\
\hline Patients group A & 0.374 & 0.00001 \\
\hline Patients group B & 0.352 & 0.00001 \\
\hline Controls & 0.458 & 0.00001 \\
\hline
\end{tabular}




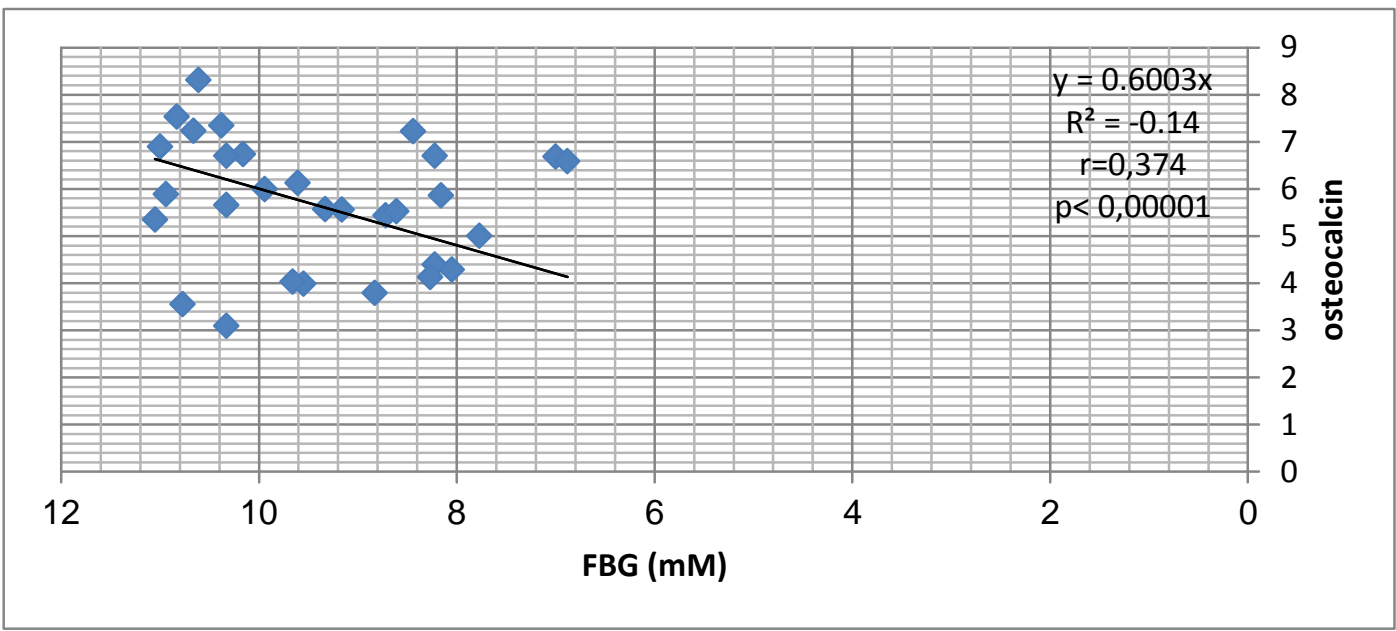

Fig.1: Correlation of serum Osteocalsin level with serum F.S.G for patients Group A

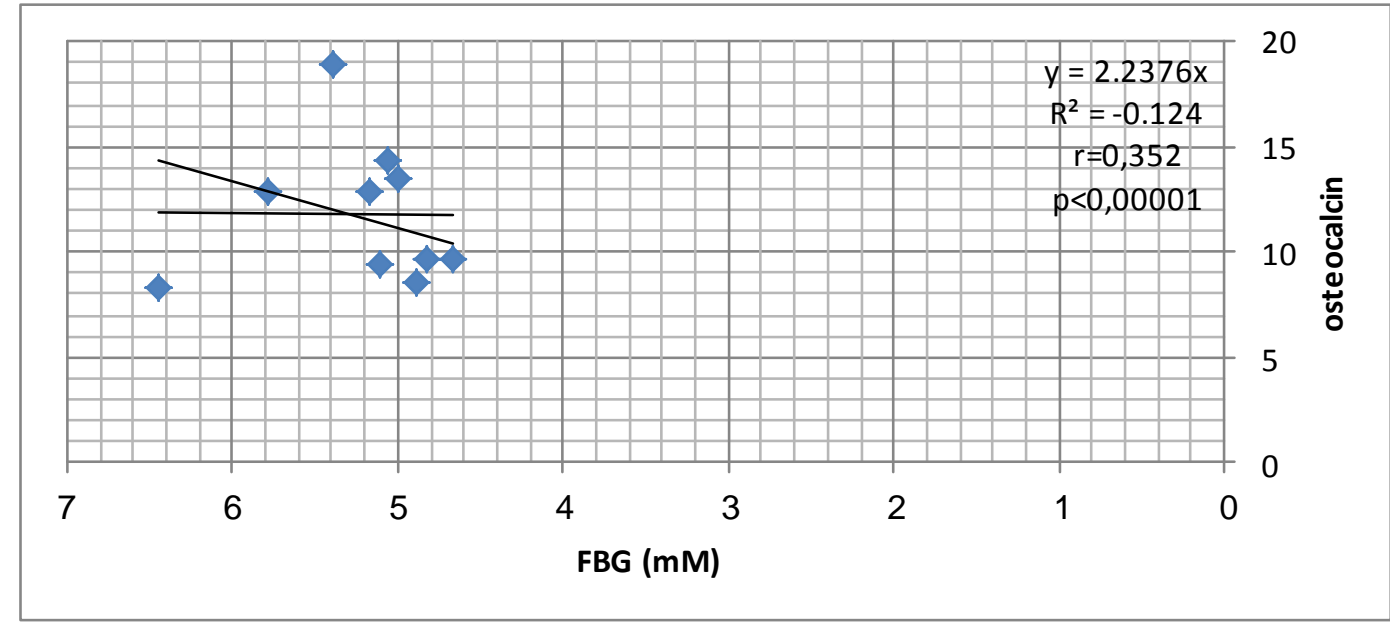

Fig. 2: Correlation of serum Osteocalsin level with serum F.S.G for patients Group B

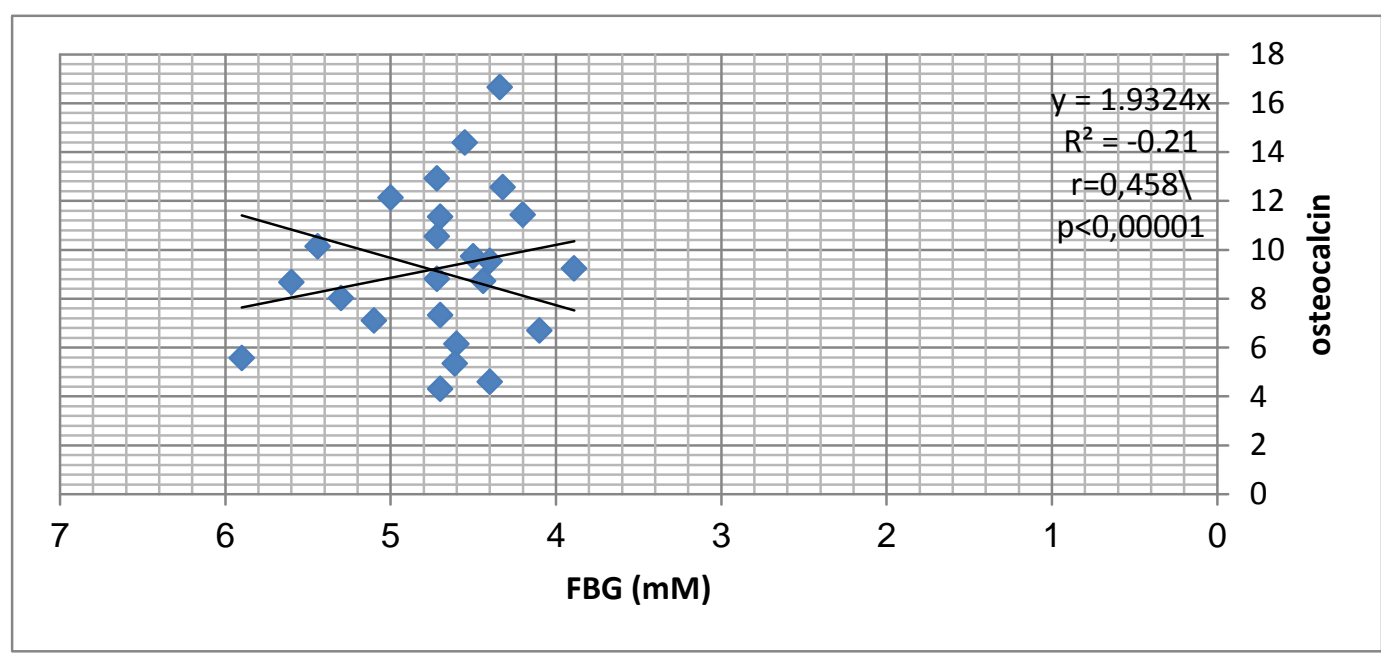

Fig.3: Correlation of serum Osteocalcin level with serum F.S.G for Control group. 


\section{Discussion:}

This study revealed that serum osteocalcin level in postmenopausal women was significantly higher than control group. This explains that the elevated level of serum osteocalcin may be associated with activity of osteoblast. Osteocalcin levels are generally increased during menopause [14]. Increased levels of osteocalcin have been reported in patients with high bone turnover osteoporosis and fractures [15]. Osteocalcin has a high affinity for calcium and exhibits a compact- calcium dependent $\alpha$-helical conformation, in which the Gla (bone gamma-carboxyglutamic acid) residues binds and promote absorption to hydroxyapatite in the bone matrix, in this way mineralization of bone takes place [16].

Deficiency of calcium in bone may lead to lowering the formation of hydroxyapatite crystals. Thus, in the state of decreased rate of bone mineralization, free osteocalcin could be available for circulation in the blood. This may explain the increased concentration of osteocalcin in the serum of osteoporotic postmenopausal women [17].
The increased levels of osteocalcin in the post-menopausal group are attributed to an estrogen deficiency, a finding which correlates to those of similar studies [18 ], which indicate a clear correlation between the estrogen deficiency and the raised osteocalcin levels. The decreased estrogen concentrations at the menopausal ages lead to a lower intestinal absorption of calcium, resulting in low serum calcium concentrations and an increased osteoclastic resorption of the bone. Both cases are leading to increase the bone turnover, thereby contributing as risk factors for the development of osteoporosis [19].

Serum (OS) levels were lower in women have osteoporosis and T2DM, reported that osteocalcin levels were founded to be lower in subjects with T2DM than in healthy people. In Another study the serum osteocalcin levels were analyzed in patients with type II diabetes and found to be lower in those with poor metabolic control in comparison to those with good metabolic control and the healthy groups [20]. Figure 1 shows the distribution of osteocalcin in serum of the studied groups.

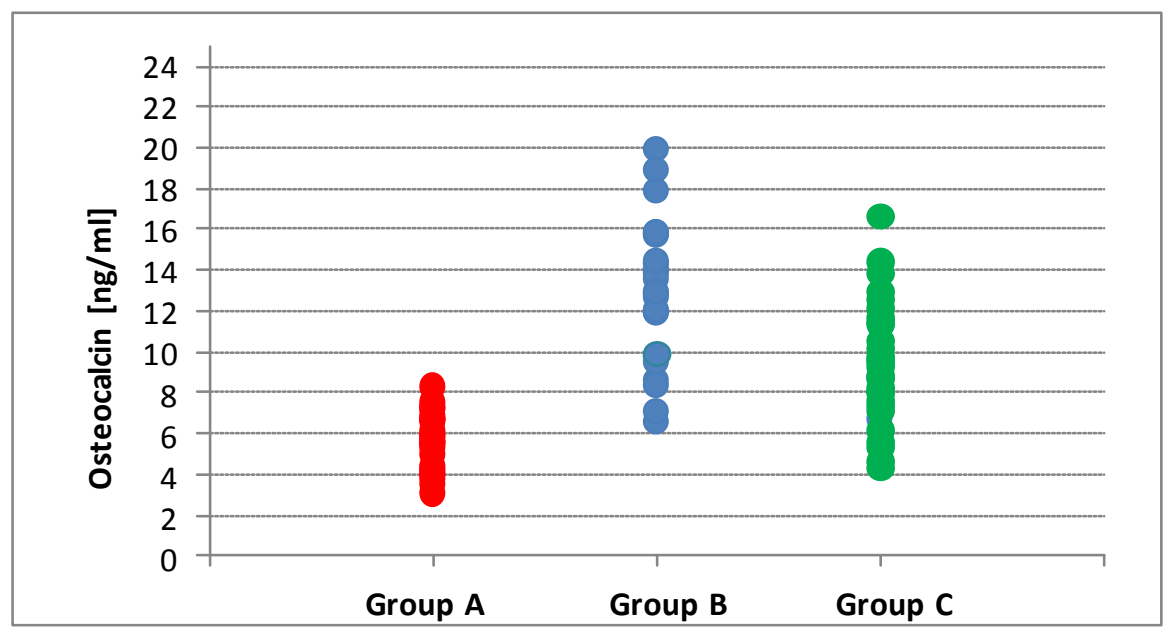

Fig. 4: distribution of Osteocalcin [ng/ml] in A group, B group and Control group.

In-vitro and in-vivo studies were demonstrated that hyperglycemia suppresses osteoblast functioning [21], and, thereby, decreased production and secretion of osteocalcin in T2DM. 
Hyperglycemia also induces increase production of reactive oxygen species (ROS), which are responsible for bone marrow ageing. However, the increasing of glucose concentration may directly be toxic to osteoblast [22].

In conclusion, osteocalcin availability in serum of postmenopausal osteoporotic women without diabetes is higher than its availability in healthy and postmenopausal osteoporotic women with diabetes. The osteoporosis is a silent disease, thus the value of osteocalcin in osteoporotic patients may be useful as a marker for this type of diseases.

\section{References:}

1. Abe, Y., İshikawa, H. and Fukaom A. 2008. Higher efficacy of urinary treatment for osteoporosis in postmenopausal women. J Exp Med. 214:51-59.

2. Fazzalarim N.L. 2008. Bone remodeling: A Review of the Bone Microenvironment Perspective for Fragility Fracture of the Hip, Osteoporosis. 19:467-472

3. Jagtap VR., Ganu JV. and Nagane NS. 2011. BMD and serum intact osteocalcin in postmenopausal osteoporosis women. Ind $\mathbf{J}$ ClinBiochem.26:70-73.

4. Moyad MA. 2004. Diopathic juvenile osteoporosis Preventing male osteoporosis: prevalence, risk, diagnosis and imaging test. UrolClinNAm: 31:321-ltimately resulting in an increased susceptibility for bone fractures.bystander.

5. Leidig-Bruckner G. and Zeigler R . 2001. Diabetes mellitus a risk factor for osteoporosis. Exp Clin .Endocrinol Diabetes: 109(12):s493- s514.

6. Brandi ML. 2010.Bone health and diabetes Medicographia: 32:364369.
7. Razzaque M. S. 2011. Osteocalcin: a pivotal mediator or an innocent bystander in energy metabolism. Nephrology Dialysis Transplantation .26 (1): 42-45.

8. Civitelli R., Armamento- Villareal R. and Napoli N. 2009. Bone turnover markers understanding their value in clinical trials and clinical practice. Osteoporosis Int. :20:853-51.

9. Villaf'an-Bernal R.,S'anchezEnr'iquez S.,and Mũnoz Valle J F., 2011. Molecular modulation of osteocalcin and its relevance in diabetes. International Journal of Molecular Medicine, vol. 28pp. 283-293.

10. Motyl KJ., McCabe LR. and Schwartz AV. 2010. Bone and glucose metabolism a two-way street. Arch Biochem Biophys. 503:2-10.

11. WHO. Assessment of fracture risk and its application to screening for postmenopausal osteoporosis. Report of a WHO Study Group. World Health Organization technical report series. 843. 1994.

12. Flier J. and Maratos-Flier E. 2005. Obesity. In: Kasper DL. Harrisons's principles of Internal Medicine, 16th ed .USA, McGrawHill Companies. 64:422-430.

13. Deurenberg, Paul; Weststrate, Jan A., Seidell and Jaap C. 2007. Body mass index as a measure of body fatness: Age- and sex-specific prediction formulas. British Journal of Nutrition 65 (2): 105-114.

14. Pino JD., Gomez EM., Rodriguez MM., Sosa CL., Cordero M., Lanchares JL. 1991. Talavera JRG. Influence of sex, age and menopause in serum osteocalcin (BGP) levels. J Mol Med. 69(24):1135-1138.

15. Liu S., Tian L., Xu P., Zhuang G., Zheng F., Tian J., Ning QL., Zhu BF., Lu SM. and Yan H. 2011. 
Analysis of correlation between blood biochemical indicators and bone mineral density of postmenopausal women. Mol Biol Rep. 38:939-948.

16. Verit FF., Yazgan P., Geyikli C., Zer Y. and Celik A. 2006 .Diagnostic value of TRAP 5b activity in postmenopausal osteoporosis. German Gynecol Assoc. 7(2):120-124.

17. Jagtap VR., Ganu JV. and Nagane NS. 2011. BMD and Serum Intact Osteocalcin in Postmenopausal Osteoporosis Women .Ind $\mathrm{J}$ ClinBiochem. 26(1):70-73.

18. Griesmacher A., Peichl P. and Pointinger P. 1997. Biochemical markers in menopausal women Scandinavian J Clin Lab Invest. Supplementary 227: 64-72.
19. Arifin Z., Hestiantoro A. and Baziad A. 2010. Giving milk fortified with high levelsof calcium andvitaminDinboneturnovermemper baili postmenopausal women. dMajObstetGinekolIndones. 34:318.11 .

20. Kanazawa I., Yamaguchi T., Tada Y. and Yamauchi $M$. 2011.Yano Swith insülin sensitivity and secretion in patients with type 2diabetes. Bone. 48:720-725.

21. Lee NK., Sowa H., Hinoi E., Ferron M., Ahn JD., Confavreuxzhang Z., Kim JK., Mauvais -jarvis F., Ducy P. and Karsenty G. 2007. Endocrine regulation of energy metabolism by the skeleton. Cell .130: 456-469.

22. Hamada Y., Fujii H. and Fukagwa M. 2009. Role of oxidation stress in diabetic bone disorder. Bone. 45: 35-38.

\section{تقدير مستوى الاوستيوكالسين في مصول النساء العراقيات المصابات بهشاشة العظام والسكري النوع في الثاني بعد سن الياس النسات}

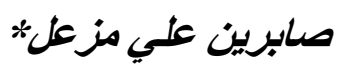

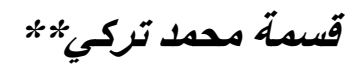

$$
\begin{aligned}
& \text { كاظم خضبرغضيب }
\end{aligned}
$$

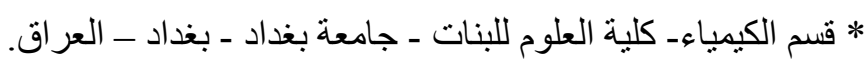

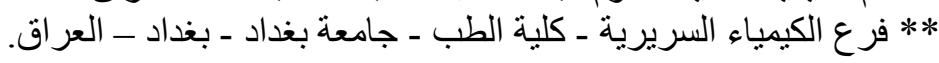

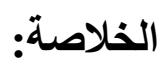

المعلومات الاساسية: هشاشتة العظام مرض يصيب الجهاز العظمي الذي بتميز بانخفاض كتلة العظم واعتلال

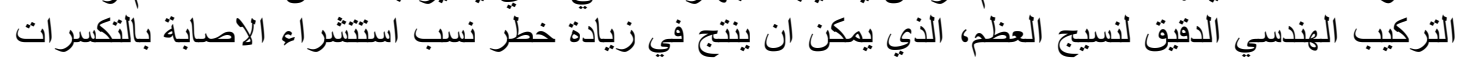

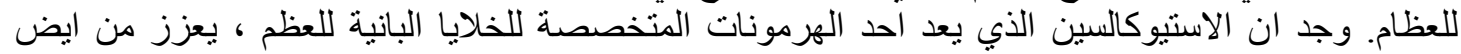

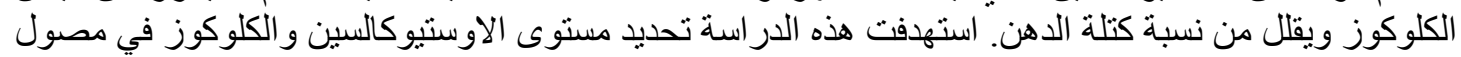

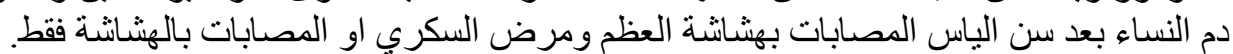

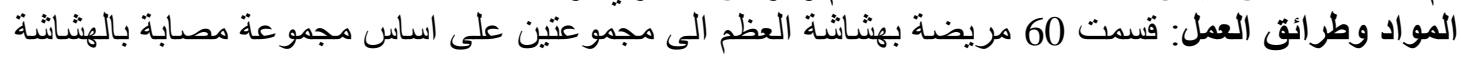

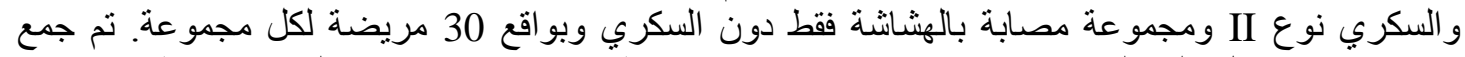

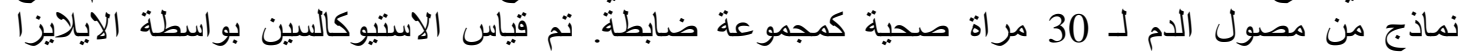

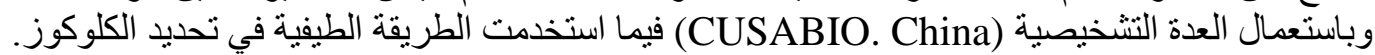

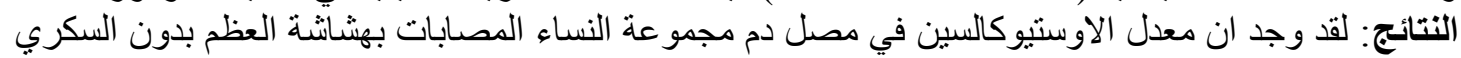

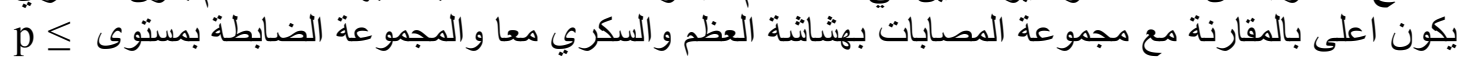

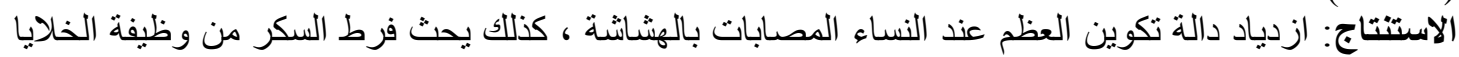

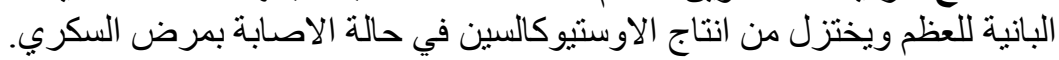

